\title{
The Treatises Named after the Prophet Muhammad ("Great Manshur and "Little Manshur") in Medieval Armenian Bibliography
}

\author{
Gayane Mkrtumyan ${ }^{1}$ \\ ${ }^{1}$ Faculty of Oriental Studies, Yerevan State University, Armenia \\ Correspondence: Gayane Mkrtumyan, Faculty of Oriental Studies, Yerevan State University, Yerevan 0025, \\ Armenia. Tel: 374-9372-6247. E-mail: gayanemkrtumyan1@gmail.com, gmkrtumyan@ysu.am
}

Received: December 14, 2021; Accepted: December 22, 2021; Published: December 23, 2021

\begin{abstract}
The present article discusses the treaties known in the Armenian medieval bibliography by the name of the Prophet Mohammad ("Great" Manshur and "Little Manshur"). It is pointed out that the above-mentioned treaties were given to the Armenians during the Arab invasions in Armenia at the end of the 7th century and at the beginning of the 8th century, but they are considered in the context of the tradition of different treaties named after the Prophet Muhammad given to the Armenians and other Christian nations. In the following centuries, the terms of the abovementioned treaties were laid down as a basis in similar covenants in the name of the Prophet Muhammad, with the new privilege - expecting the Muslim authorities to protect their rights from possible encroachments.
\end{abstract}

Keywords: the Prophet Muhammad, "Great" Manshur, Catholicos of All the Armenians, Arab invasions

\section{Introduction}

In the Armenian medieval historical tradition the treatises named after the Prophet Muhammad, the founder of Islam, are known as Ali Manshur (treaty), which were aimed at preserving and establishing ethnic and ecclesiastical rights of the people under the Islamic rule. From these treaties, the "Great Manshur" and the "Little Manshur") have been separated and studied as the work of the Prophet Muhammad, but they have not yet been thoroughly studied by native historians (Papazyan, 1956, pp. 97-100). Having carried out a research of the early medieval Armenian Arab period the authors briefly referred to the above-mentioned treaties-manshurs, which have played a major role in the life of the Armenian population.

Hence, this is the main reason for having chosen the particular topic for the research. Besides, the aim of the present article is to publicize and put those very documents and their observations into scientific circulation, to prove the current viability of those agreements and their adaptation, which had for many centuries been the pledge for the Armenian population to protect their interests from Muslim rulers.

These two treaties which are found in medieval Armenian bibliography are based on the terms of these two treaties given to non-Christian and heterodox population of the Arabic peninsula by Muhammad and are mentioned by Muslim historians. (Bālādhurī 1983, pp. 69-84), according to which the population was assured to receive safety and security of life and property, security of churches, in return of paying taxes and being under the auspices of the Muslim community.

The treaty given by the Prophet Muhammad to the Christian population of the city of Najran, Yemen, in 632, is of great importance for carrying out a research of the history of the relationship between the Muslim rulers and the Christian population by which the life, faith, churches and property of the city population should pass to the patronage of Allah and be taken under the protection of the apostle Allah Muhammad.

The issue of the Christian population of Najran was to be resolved with justice (Bālādhurī p. 21). In addition to this version of the treaty, which was preserved in the works of Muslim historians of the 9-12th centuries, there exists also another treaty given to the people of Najran by the name of the Prophet Muhammad which was included in the anonymous "Nestorian History". In this version, the Prophet Muhammad enters into a treaty with all those who profess the Christian religion. It was also concluded for the next generations of Muslims, so that the latter would recognize the rights of the Christians and take them under their auspices (Sher 1918 p. 605). The Najran Treaty is a vivid example of the Prophet Muhammad's tolerance of the Christian population, in the context of which the treaties given to the Armenians and various Christian communities should also be considered in the name of the Prophet Muhammad. 
Referring to the "Great" Manshur mentioned in Armenian bibliography named after Muhammad, it should be stated that the Armenian-Arab cooperation had started even earlier, when Armenian Patriarch of Jerusalem Abraham (died in 669) after witnessing the success of Islam during the reign of the Prophet Muhammad, entered Madinah accompanied with the delegation of Christians, wishing to get a special agreement aimed at ensuring the security of the Armenian community of Jerusalem, according to which a number of sanctuaries of the city came under the jurisdiction of the Armenian community. This is mentioned by Tigran Savalanyan, a scholar of Jerusalem history, who had obtained this information from treatise of the Arab historian Zeki ed Din "The Victory of Jerusalem (Savalanyan 1930, p. 413)". The researcher of the issue G. Grigoryan in his paper "Through the Armenian Needle Hole" included excerpts from Tigran Savalanyan's work, where the above-mentioned events and the text of the treaty given to Patriarch Abraham by Muhammad are given in English translation (Krikorian 2002, p. 22', see also https://www.mdpi.com/2077-1444/12/2/138). The above mentioned treaty was ratified by the caliphs Omar ibn al-Khattab (634-644) and Ali ibn Aru Talib (656-661) (Savalanyan, p. 271).

Salah al-Din the founder of the Ayyubid dynasty (died in 1193), reaffirmed the above-mentioned treaties in a special proclamation recognizing by each other the powers of the Armenian community over a number of the city churches (Savalanyan pp. 438-413). The English translation of his contract is available in Dadoyan's work (Dadoyan 2013, II p. 16-170). Later, based on these documents, the Ottoman sultans also recognized the rights of the Armenian community in Jerusalem and the rights of the Armenian Patriarchy of the city considering certain sanctuaries. (Ormanyan 2001, I, p.213). The treaty given to the Armenian community of Jerusalem by the Prophet Muhammad is the earliest evidence of the Arab-Armenian contacts and marks the first stage of the Armenians reaching an agreement with the Arab-Muslims (Dadoyan 2011, I, p. 52). The Armenian community has created a rich cultural heritage in Jerusalem since the earliest times of the establishment of Christianity, taking an active part in the caring life of the city. So, this fact should not have been remained unnoticed by the Arab caliphs and later Muslim rulers who gave special privileges to the Armenian community for the sanctuaries and monasteries built for the city by the Armenians as early as during the patriarchy of the Armenian Catholicos S. Gregory the Illuminator (302-326).

In the context of the treaties given by Muhammad to the Armenian community of Jerusalem and subsequently ratified by the caliphs and the Muslim rulers and sultans, it is also necessary to refer to the year of 652 when the treaty was signed between the Armenian prince Theodoros Rshtuni (639-654) and the governor of Assyria Muayya ibn Abu Sufyan (639-661), about which is mentioned by the 7th century Armenian historian Mebeos. According to the terms of the treaty, Armenia was exempted from fulfilling its tax obligations to the Arab Caliphate for three years; only after the expiration of the term did it have to pay the royal tax, the amount of which would be determined by the Armenians. The latter was allowed to have a fifteen-thousand cavalry, which was obliged to take part in the battles everywhere except Assyria. In the event of an attack by foreign troops, the Arabs pledged to help the Armenians (Sebeos p 65). With this treaty, Armenia gained some autonomy and Armenian ministers were to be considered as subjects of the Caliphate, but would retain their inherited land rights and other privileges. The above-mentioned agreement was the first official diplomatic document that determined the political situation in Armenia and the prospects for its further development. It should be noted that no country conquered by the Caliphate had received such broad rights and powers as Armenia did under the treaty. The historical-comparative method of research has been used while making a comparison between the terms of treatises given by the Prophet Muhammad to the Christians of Najran, the Armenian community of Jerusalem and the content of the "Great" and "Little" Manshurs", mentioned in Armenian manuscripts.

\section{Great Manshur}

This treaty, mentioned in Armenian bibliography by the name of the Prophet Muhammad, was first mentioned in the "History" by the 12th-Century Armenian Historian Samuel Anetsi. He briefly recalls the Prophet Muhammad's activity, the Arab invasions to Armenia, Persia, Egypt and notes that the Prophet Muhammad banned the sword obeying him most of the universe. "And he signed a bill with an unforgettable oath:

The Armenian world has the courage to have Christianity, also to sell and buy for at least 5 drams for a deer's donkey's bag $=7$ ropes for a hair and a handkerchief. And not take any tax from the priests or the horsemen (Anetsi, 2011, p. 400)".

Having analyzed the terms of the treaty, the researchers note that the coin was the silver coin used in the Middle East in the 7th century, and the four drams were equal to two roubles of vost, and three bolts of sifted wheat weighing two puts (Manandyan 1960, p. 212). The "free men" were landowner-noblemen. The cavalry mentioned in the treaty was probably the so called ayrudzi made of warriors existing in the region of Armenia. It is worth noting that this cavalry, like the "free men" included in the treaty, during the Omayyad Caliphate received a special 
salary of one hundred thousand dahekan per year in Armenia (Manandyan, p. 212). The 8th-century Armenian historian Ghevond writes that the Arabs paid the Armenian cavalry in an attempt to place some of their military responsibilities on a local contingent (Ghevond 1982, p.). The above mentioned treaty which is considered to be the first written mention of the naming "Great" Manshur is found in the book of 14-15 th century Armenian chronicler Grigor Tatevatsy's "Book of Inquiries" in the chapter of "Against Tachkats". The author mentions that in the tenth year of the Armenian Great Year and the Tenth Year of Yezr Catholicos someone named Mahmet of the tribe of Ismael, Abdul's son, signed a bill-treaty with an unforgettable oath to the Armenian world, which is now called the "Great Manshur" (Tatevatsi, 2009, p. 53). The historian then writes the text of that agreement. As we can see, in the example of the already mentioned treaty by Grigor Tatevatsi, it is written that during the time of the Catholicos (630-641) Muhammad the Prophet signed a treaty with the Armenian world on the condition of paying taxes, from which the clergy and the noblemen were exempted. It is well known that Muhammad passed away in 632, so he could not have signed this treaty. According to the famous Armenian scientist, an expert of Arabic studies Aram Ter-Ghevondyan, Samuel Anetsi had only confused the name of the viceroy Omayan Muhammad ibn Mrwan with the name of the founder of Islam in this important document and this is the reason why it was traditionally fixed in the Armenian history writing that the Prophet Muhammad signed an agreement with the Armenians to recognize their rights (Ter-Ghevondyan 2003, p. 294).

Samuel Anetsi and other medieval Armenian historiagraphers, namely, Kirakos Gandzaketsi and Mkhitar Anetsi, relaying the text of the treaty, do not cover under what circumstances it was given to the Armenians.

In his "History" Samuel Anetsi writes that "the Arabs massacred Bznuni and Aghivit and Taron", probably referring to the first Arab invasions to Armenia, later he refers to the above-mentioned treaty named after the Prophet Muhammad. The Arab invasions to Armenia started in the 640s. The Armenian-Arab covenant was signed in 652, but it was not considered to be a document in which the fact of Armenia's final conquest was recorded. In 654 the Arabs occupied the villages and towns of Armenia, giving peace treaties to the population. The Arab historian al-Balazuri points out the treaty given by the general Habib ibn Maslama to the population of the city of Dvin being then the capital of Armenia, by which the Christians of the city, the Zoroastrians, received security for their property, churches, and city walls (Bālādhurī p. 199). In 660s the Caliphate was at war with the Byzantine Empire, and during this period Armenia enjoyed extensive autonomy and a peaceful life. But already in 689 chaliph Omayyan Abd al-Malik (665-705) after having finally defeated the Byzantine Empire and having solved the internal problems of his country, appointed his brother Muhammad ibn Mrwan as the ruler of Atrpatakan and Armenia in 701. It is said that this treaty named after the Prophet Muhammad and which is mentioned by Samuel Anetsi, probably refers to this very period as well. From the above mentioned it becomes clear that this treaty was signed during the Arab invasions. Thus, the present treaty, which stated the final conquest of Armenia by the Arabs, is a historical document given to the Armenians, most likely signed by the successor Muhammad ibn Mrwan (Mkrtumyan 2017, p. 92).

It is believed that Samuel Anetsi tried to make the treaty obsolete by attributing it to the eve of an earlier period, particularly the Arab conquests. It is observed that all Armenian chroniclers are inclined to attribute the signing of the treaty to the time of the Prophet Muhammad, and the more they tend to do that, the higher it acquires weight and dignity.

\section{3. "Little" Manshur}

The other treaty with a religious content is known as "Little" Manchur in Armenian literature. This is mentioned by Grigor Tatevatsi, a chronicler of the 14th-15th centuries. He writes that the other Mahmed gave the small proclamation to the Armenians "to be free from all taxes, like the proclamation of the first Muhammad, in accordance to which the priests, nobles and horsemen should be free from all taxes" (Tatevatsi p. 53). For the study of the subject matter, the question of the circumstances under which the agreement was given to the Armenians is of great importance. Armenian sources present these issues in great detail. It should be noted that in the Middle Ages the Armenian Catholicos was not only the caring leader of Armenia, but he also played an important role in the political life of the country.

In the time of the Arab conquests and during the rule of the Caliphate in Armenia, it was the Armenian Church that was to represent the Armenians during the discussion of the treaties with the Caliphate.

There is a record in Armenian historiography, according to which in the 8th century the Armenian Catholicos Hovhannes Odznetsi (717-728) visited the caliph Omayan Omar II (717-720) and received a religious contract from him with the following conditions: not to force Christians to renounce their faith, to exempt the caring class from taxes, and that in a Muslim state Christians can have the right to practice their religion freely. At the request of the Catholicos, the Caliph signed the treaty with his ring, giving lavish gifts to Hovhannes Odznetsi and sending 
him to Armenia with great honor (Gandzaketsi 1982, p. 60). Thus, the Omayyad Abd al-Malik Caliph, suppressing the riots in different parts of the Caliphate, carried out a number of events inside the country, and passed on to the final stage of the Arab conquests. For that purpose, it was inevitable to destroy the Byzantine Empire completely, occupy and take under the control the strategic dispositions of the Armenian plateau. In 699 Muhammad ibn Marwan launched a great campaign against Armenia. The 8th century Armenian chronicler Ghevond writes that the Arab authorities in Armenia did not want to recognize the hereditary rights of the Armenian ministers anymore; and that the Armenian ministers had already been aware of it (Ghevond, pp. 31-32). In 703 a fierce battle took place between the Arab cavalry "ministerial regiment" near the village of Vardanakert which ended with the victory of the Armenians. And when the news of the defeat of the Arabs reached the caliph, he ordered Muhammad ibn Mrwan to attack Armenia, to drown in blood the revolts which began after the battle. Unable to organize necessary resistance against the enemy, Armenian ministers send Armenian Catholicos Sahak Dzoraporetsi (677-703) accompanied with a number of bishops to the Arabs to carry on negotiations and peace talks.

The chronicler Ghevond mentions that when the Catholicos arrived in the city of Harran, being aware of the imminent end, wrote a letter to the Arab general, confirming that the Armenian nation was ready to be obedient and submissive, instead asking him to stop the bloodshed and show tolerance. In his letter to the Arab general, the Armenian patriarch concluded an alliance in the name of the living God, according to the covenant he had made with the Arab ancestor Ishmael, asking him to grant the Armenians peace on the condition of paying taxes to them.

The Catholicos urged the commander-in-chief to refrain from looting and bloodshed, persisting that otherwise "the Lord will turn the heart of his army" and the soldiers would not obey his orders (Ghevond, p. 33). When Muhammad ibn Marwan read the letter, he came next to the body of the deceased with a special bow to him. Then he took the Catholicos by the hand, saying that he had learned about the wisdom of the Armenian Catholicos from the note he received, where he was introduced as a brave shepherd who had come out to carry a struggle with his sword. And at his request, he gave a written oath to the Armenian bishops (Ghevond, p. 34). The oath guaranteed only the freedom of religion, but not the rights of the land inheritance for the ministers. This is the very historic document known in Armenian medieval bibliography as "Little" Manchur, which, unfortunately, has not come to our hand and the content of which has not been preserved in the works of the Armenian historians either.

10th century Armenian historian Hovhannes Draskhanakertsi adds new details to the above-mentioned cases in his "History". In a letter to the Arab general, Catholicos Sahak asked him to give a permission to put the letter in his right hand after his death, so that the Arab general would not regret or refuse to carry out his intentions. When the latter came to the Catholicos "pronouncing salamalec", the Catholicos's hand, laying still and breathless on his side, moved and came to life" at that very moment "against the policeman because he had begged" (Draskhanakerttsi 1991, p. 100). Later Armenian chroniclers referred to the already mentioned historical facts relying on the information mentioned in the original sources presented by Ghevond and Hovhannes Draskhanakertsi. The above-mentioned cases are also present in the history of the Anonymous Conversation Scribe of the 10th-11th centuries, attributed to the 10th century chronicler Shapuh Bagratuni. This source also refers to the letter written by Catholicos Sahak addressed to Muhammad ibn Mrwan, according to which the Catholicos took "the written message and the law of his father Muhammad to the Arab general, asking him not to hesitate, and "make us safe from you lest he see the Lord God bewildered in our hands... "(Anonymous Conversation Scribe 1971, p 25). It is evident that, the legend of the Prophet Muhammad's "letter" to the Armenian world did already exist in the Armenian historical reality in the 10th-11th centuries, about which is mentioned by the Anonymous conversation writer.

In the following centuries, when the persecution of the Christian-Armenian population got intensified by the Muslim rulers, treaties named after the Prophet Muhammad began to be circulated for the protection of the rights of the Armenian population, based on the contents of the "Great" and "Little" Manshurs and other cases related to them.

The document was constantly being changed and adapted to the time and conditions

Thus, the "Great" and "Little" Manshurs" which were mentioned in medieval Armenian literature and were most probably given to the Armenians by the general Muhammad ibn Mrwan, date back to the beginning of the 8th century.

The "Great Manshur" agreement is about the tax obligations imposed on the Armenian population, whereas the"Little Manshur" had a religious content but the text of which has not reached us.

It is due to their content that the differences between the names of two Manshurs can also be interpreted. It is called "Great" Manshur, because the treaty in addition to the term for the freedom of religion also defines the tax obligations of the population, while the other one is called "Little Manshur" as the religious freedom is elucidated 
only through the personality of Catholicos Sahak Dzoraporetsi, who assumed the role of the leader in the meeting with the Arab general, trying to establish peace with the Arab general on behalf of the Armenians. In addition, the "Little" Manshur given by the latter was possibly a special tribute in the honour of the Armenian Catholicos.

\section{Representation of the Content of "Great" and "Little" Manshurs" in Arabic Letters of Matenadaran}

In the following centuries, the content of the above-mentioned treaties and related cases were applied in various documents and records compiled in the name of the Prophet Muhammad kept in the Matenadaran. Officially Matenadaran is known as the Research Institute of Ancient Manuscripts after Mesrop Mashtots. It is located in Yerevan - the capital of Armenia and was founded in 1959 during the Soviet Union. The Yerevan Matenadaran was established as a manuscript research and preserving centre on the basis of the manuscripts created and preserved in Catholicosate Matenadaran of Etchmiadzin and different manuscript centers of Armenia. Besides Armenian, manuscripts in the Arabic, Persian, Greek and other languages are also kept here.

In the Persian Documents Fund of the Matenadaran a document under the title "Document 21" is kept which has been elucidated by the great Armenian scientist Hakob Papazyan. The document refers the issues of tax immunity of the Armenian clergy. The treaty mentions that Catholicos Sahak Dzoraporetsi (in the document, Catholicos Isahak) went to meet General Muhammad and enter to an agreement with him (Papazyan, p. 70). However, instead of General Muhammad (who is actually Muhammad ibn Marwan), the name of the Prophet Muhammad is mentioned, who had left Mecca and Medina and with the intention of conquering new lands had drawn near the border (probably of Armenia). It is obvious that the Prophet Muhammad carried out his political and religious activities mainly in 610-632, and the Catholicos Sahak Dzoraporetsi in the late 7th and early 8th centuries.

If medieval Armenian historiagraphers claim that upon his arrival in Harran the Catholicos left a letter to the Arab general to be handed after his death and where he was asking to grant his country peace, freedom of religion, it means that according to this document, the Armenian Catholicos's request is quite certain and that by the covenant of the Prophet, the inhabitants of a number of provinces of Armenia should pay church taxes to the Monastery of Akhtamar.

We assume that this document was compiled on the initiative of the Akhtamar Catholicosate to obtain a certain privilege from Karakhan Bey, the governor of the Vostan region of Armenia. The Armenians were obliged to pay taxes "... half a module of grain, 1 horse's bag, one rope" (Papazyan, p. 71).

These tax terms are taken from "Great" Manshur. The ratification of the documents was initiated by Catholicos Grigoris Akhtamartsi (1512-1544). The names of the five witnesses are mentioned at the end of the covenant and that this sacred writing was put down in the fourth year of the Prophet's appearance by Muawiya ibn Sufyan ibn Makum himself (\# a3azjan, 15 72). We believe that this document was compiled in the name the Prophet Muhammad to establish the rights of the Armenian people from Bey Karakhan, which could have had an impact on other prominent Muslim people and officials, facilitating the ratification of this document by the Muslim rulers of later centuries.

\section{Conclusions}

1). The treaty by the Prophet Muhammad given to the Christian population of the city of Najran given as early as 632 lies on the basis of "Great" and "Little" Manshurs" established in Arab and Christian sources, in the context of which the two Manshurs should be considered.

2). The treaty given to the Armenian community of Jerusalem reaffirmed by the later caliphs and Muslim rulers is especially important which was once again proved later by "Great" and "Little" Manshurs", as well as by the covenants given to the Armenian population by the Arab troop commanders during the Arab conquests.

3). The study of historical facts shows that the ""Great" and "Little" Manshurs", were given to the Armenian population at the beginning of the 8th century by the general Muhammad ibn Mrwan. The terms of the "Great" Manshur confirm the fact of the final conquest of Armenia by the Arab Caliphate.

4). The content of the above-mentioned treaties and related cases we have studied were used in the documents drawn up in the name of the Prophet Muhammad to protect the rights of the Armenian population and to obtain new privileges from the Muslim rulers.

\section{References}

Anetsi, S. (2011). Collection of Writer Historians, Yerevan, Nairi Publishing House al-Baladhurī, Ahmad ibn Jahyā Jabir, 1982, Bauirut, Mu' assasat al-M a' arif.

Dadoyan, S. B. (2011). The Armenians in the Medieval Islamic world. Paradigms of interaction seventh to fortheenth centuries, vol 1. The Arab period in Armenian seventh to Eleventh centuries. New Bronswick and 
London.

Dadoyan, S. B. (2013). The Armenians in the Medieval Islamic world. Paradigms of interaction seventh to fortheenth centuries, vol 2. The Arab period in Armenian seventh to Eleventh centuries. New Bronswick and London.

Gandzaketsi, K. (1982). Armenian History, "Soviet Writer" Publishing House.

Gayane, M. (2017). Charter-Treaties as a Source of Armenian-Arab Relations (VII-XII centuries), Yerevan, "Mughnis" Publishing House. Retrieved from https://www.mdpi.com/2077-1444/12/2/138

Ghevond, H. (1982). Yerevan, "Soviet Writer" Publishing House.

Grigor, T. (2009). Against Tachkats, Yerevan, "VMV Print" Publishing House.

History of Anonymous Conversation Writer. (1971). Yerevan, Publishing House of the Armenian SSR Academy of Sciences.

Hovhannes from Draskhanakert. (1996). Armenian History, YSU Publishing House.

Krikorian, G. (2002). Through the Eye of an Armenian Neadle, Antelias; Lebanon.

Manandyan, H. (1960). Works, volume B, Yerevan Publishing House of the Academy of Sciences of the Armenian SSR.

Ormanyan, M. (2001). In Azgapat, the Holes of the Armenian Orthodox Church from the beginning to the present day, narrated with related national items, v. A, Mother Seat of Holy Etchmiadzin.

Papazyan, H. (1956). Persian documents of Matenadaran, volume A (17th-16th centuries), Yerevan, USSR Academy of Sciences Publishing House.

Savalanyan, T. (1931). History of Jerusalem, vol. 1-2, Jerusalem, printing house of St. Hagopian.

Sebeos (1979). History, Yerevan, Publishing House of the Academy of Sciences of the Armenian SSR.

Sher, A. (1983). Histoire Nestorienne Inédite: Chronique de Seért, Patrologia Iroentalis, Tome XIII, Fascicule 4, №5, 1918, Turnhout: Brepols.

Ter-Ghevondyan, A. (2003). Collection of Articles, Yerevan, YSU Publishing House.

\section{Appendix}

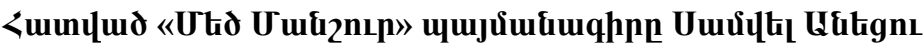

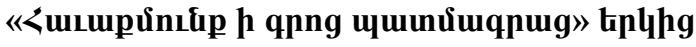

Gı Uuhứtunu uju unqtal qunıpq, lı puahı hupuunnı \&nnu

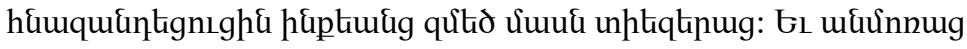

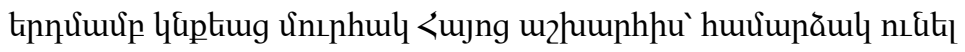

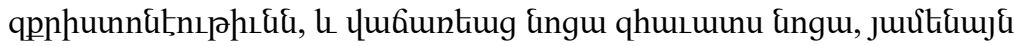

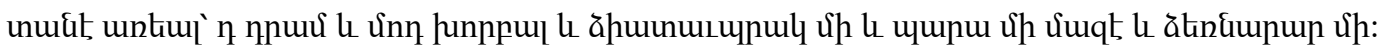

Translation of the "Great Manshur" from Samuel Anetsi's "Writings from the Book of Historians".

And this Muhammad ... (from the nation of Ismail, the son of Haangar)(1), forbade the sword and most of the universe obeyed him and all his instructions. And he signed a promissory note with an unforgettable oath to boldly profess Christianity with the Armenian world, sold them their faith, took money from each house $d \operatorname{dram}(2)$ and $g$ mod $\operatorname{khorbal}(3)$, a horse bag, a big rope and a craftsman.(4) " And he ordered not to take taxes from the clergymen, noblemen and horsemen.

(1) This was quoted from Samuel Anetsi's narrative to show who he was about.

(2) The 'd' dram was the silver coin used in the Middle East in the 4th century

(3) The mod khorbal was sifted wheat that weighed two bags. 
(4) The Arabs took the above mentioned horse bag (double bag), hair rope and gloves for the needs of their own army.

\section{Copyrights}

Copyright for this article is retained by the author(s), with first publication rights granted to the journal.

This is an open-access article distributed under the terms and conditions of the Creative Commons Attribution license (http://creativecommons.org/licenses/by/4.0/). 